\begin{tabular}{|l|l|l}
\hline Comstruction and Material Journal & $\begin{array}{l}\text { Colume 3 No.2 } \\
\text { e-ISSN 2655-9625, http://jurnal.pnj.ac.id/index.php/cmi }\end{array}$ & Juli 2021 \\
\hline
\end{tabular}

\title{
STUDI NILAI KUAT GESER TANAH LUNAK BERDASARKAN BESARNYA PENURUNAN YANG TERJADI
}

\author{
Istiatun $^{1}$, Handi Sudardja ${ }^{2}$, Yuwono ${ }^{3}$ \\ 1,2,3 Jurusan Teknik Sipil, Politeknik Negeri Jakarta, Jl. Prof. DR. G.A. Siwabessy, Kampus UI, Depok, Jawa Barat, \\ 16424. \\ e-mail: istiatun@sipil.pnj.ac.id, handi.sudardja@sipil.pnj.ac.id, yuwono@sipil.pnj.ac.id
}

\begin{abstract}
Soft soil is not suitable for supporting construction that stands on it because it has low shaman power, high compressive properties, and little stability. The compressibility of the soil certainly affects the existing construction, especially if the settlement that occurs due to the compression of the soil is not permitted. While the low bearing capacity of the soil causes the design load cannot be carried out directly, it is generally given in stages. The advantage of providing the load that gradually causes the density of the soil will increase. The soil with increased density will increase the carrying capacity of the soil so that it can accept the load of the next stage. Increasing in bearing capacity is given due to the magnitude of the land subsidence that occurs. It is necessary to test with laboratory modeling. Soil samples were put in the test basin and given additional water to determine how things were in the field if the soil experienced an increase in water content. Soil samples were loaded and recorded the amount of settlement that occurred. Increasing bearing capacity by conducting direct shear test changes in the soil bearing capacity parameter values is known to correlate the magnitude of the decrease in soil that occurs. In addition, an analysis of changes in water content and soil volume weight was also carried out due to the magnitude of the decrease. From the test modeling results in the laboratory with a test basin, it was found that the greater the value of soil subsidence, the higher the cohesion value of the soil and the lower the shear angle in the soil. For soil, water content is inversely proportional to the decrease, the more significant the decrease, the smaller the water content. Meanwhile, the weight of the soil volume is directly proportional; the more significant the decrease that occurs, the greater the weight of the volume of the soil.
\end{abstract}

Keywords: settlement, shear strength parameter, soft soil, direct shear test.

\begin{abstract}
ABSTRAK
Tanah lunak merupakan tanah yang kurang baik untuk mendukung suatu konstruksi yang berdiri diatasnya karena memiliki daya dukung yang rendah, sifat memampat yang tinggi dan memiliki stabilitas yang kecil. Sifat mudah memampat akan berpengaruh terhadap kegagalan konstruksi yang ada, jika penurunan yang terjadi melebihi penurunan yang diijinkan. Sedangkan daya dukung tanah yang rendah akan berpengaruh pada pembebanan yang dilakukan di lapangan, dimana beban diberikan secara bertahap. Beban tahap selanjutnya dapat diberikan setelah tanah mengalami penurunan akibat beban sebelumnya yang bekerja pada waktu tertentu, dimana kepadatan tanah dan kadar air tanah akan berubah. Hal ini mempengaruhi kekuatan tanahnya, dimana bertambahnya kepadatan tanah tentunya akan mempengaruhi perubahan nilai parameter kekuatan geser tanah yang dapat diketahui melalui hasil uji geser langsung. Untuk itu, maka dilakukan penelitian dengan model di laboratorium menggunakan bak uji, sehingga didapatkan parameter kekuatan geser dan korelasi antara besarnya penurunan tanah yang terjadi terhadap perubahan kuat geser tanah. Bak uji diisi dengan tanah yang dibuat jenuh, kemudian dipasang vertikal drain dan dibebani dengan pelat baja. Pembebanan pada bak uji dilakukan dengan waktu yang berbeda-beda sehingga akan mendapatkan besar penurunan tanah yang berbeda pula. Dari hasil pemodelan uji di laboratorium tersebut, didapatkan bahwa semakin besar nilai penurunan tanah, maka akan bertambah nilai kohesi tanahnya dan semakin berkurang sudut geser dalam tanah tersebut. Untuk kadar air tanah berbanding terbalik dengan penurunannya, semakin besar penurunan yang terjadi maka semakin kecil kadar airnya. Sedangkan untuk berat volume tanahnya adalah berbanding lurus, semakin besar penurunan yang terjadi maka semakin besar berat volume tanahnya.
\end{abstract}

Kata kunci: penurunan, parameter kuat geser, tanah lunak, uji geser langsung. 


\section{PENDAHULUAN}

Mendirikan suatu konstruksi atau bangunan di atas tanah lunak dalam jangka waktu yang cukup lama, akan menimbulkan terjadinya pemampatan tanah yang akan berpengaruh pada konstruksi atau bangunan tersebut. Selain itu tanah lunak merupakan tanah yang mempunyai daya dukung yang rendah, dimana hanya mampu mendukung beban sesuai dengan daya dukungnya. Jika beban yang bekerja melebihi maka pemberian beban dilakukan secara bertahap, dimana penambahan beban tahap berikutnya tergantung dari peningkatan parameter kuat gesernya akibat bertambahnya berat volume tanah. Menurut ahli geoteknik (Skempton dan Henkel 1953, dalam Indrasurya B Mochtar 2000) bahwa $\mathrm{Cu}$ (kohesi) tanah sebagai parameter kuat geser tanah akan bertambah tergantung dari tegangan dan indeks plastisitas tanah, dengan persamaan: $\mathrm{Cu} / \sigma p^{\prime}=0,11+0,0037$ (PI). Peningkatan nilai daya dukung tanah (CBR) meningkat sebesar $71,016 \%$, kondisi unsoaked dan $225,042 \%$ untuk soaked, akibat tanah lunak distabilisasi dengan kapur dan diperam selama 28 hari (Ario Widio Laras dkk 2017). Peningkatan nilai parameter kuat geser yaitu $\mathrm{Cu}$ (kohesi) meningkat terbesar pada daerah sekitar kepadatan maksimum (Arinda Rahma Dianing Putri dkk 2018). Tanah setiap mengalami penimbunan secara bertahap menjadi lebih kuat dikarenakan terjadinya kenaikan kekuatan tanah (gain strength).

Kepadatan tanah lempung lunak meningkat $17 \%$ yang distabilisasi dengan campuran $25 \%$ arang kayu dan meningkatkan kuat geser tanah $(\mathrm{Su})$ sebesar $\quad 75 \% \quad$ (Rusdiansyah,2018). Kenaikan kohesi terbesar pada tanah penurunan terbesar akibat waktu pembebanan selama 9 hari dimana tanah dengan kepadatan terbesar (Wahyu
Wijaya \& Istiatun 2017). Kenaikan harga kekuatan geser tanah sebesar $116,34 \%$ pada tanah yang dicampur dengan gypsum sebanyak $8 \%$ dengan waktu pemeraman 14 hari. Karena gypsum mengandung kalsium yang mengikat tanah bermateri organik terhadap lempung dan Gypsum juga lebih menyerap banyak air sehingga membuat campuran limbah dan sampel tanah akan menjadi semakin keras dan kuat, sehingga dapat meningkatkan nilai kohesi tanah yang menjadikan tiap tiap partikel tanah terikat dengan kuat dan berpengaruh pada peningkatan nilai kuat geser tanah lempung, (Arif Wibawa, dkk 2015). Nilai $\gamma_{\mathrm{dmax}}$ tanah menjadi $1.265 \mathrm{gr} / \mathrm{cm}^{3}$ dan tegangan geser terbesar yaitu $\tau=12.4899 \mathrm{kN} / \mathrm{m}^{2}$ dengan campuran $25 \%$ abu batu bara tetapi nilai kohesi terbesar yaitu 6.3526 $\mathrm{t} / \mathrm{m}^{2}$ pada campuran $20 \%$ abu batu bara. Sedangkan untuk nilai sudut geser dalam $(\varnothing)=17^{\circ}$ pada campuran $15 \%$ dan 25\% abu batu bara (Sindy Natalia Polii, dkk 2018). Melihat penelitian sebelumnya, tentang perubahan nilai kekuatan geser tanah lunak akibat pembebanan maupun pemadatan tanah dengan stabilisasi yang meningkatkan kepadatan tanah. Maka perlu dilakukan penelitian lanjut tentang perubahan nilai kekuatan geser tanah ditinjau dari parameternya akibat penurunan yang terjadi yang disebabkan tanah tersebut memampat akibat beban yang bekerja di atas tanah lunak tesebut. Sedangkan untuk mengetahui hal tersebut, maka dilakukan penelitian dengan skala model di laboratorium dengan menggunakan bak uji berukuran $120 \mathrm{~cm}$ x $60 \mathrm{~cm} \times 80 \mathrm{~cm}$, dimana sampel tanah dimasukkan dalam bak uji setinggi $50 \mathrm{~cm}$, kemudian dipasang vertical drain untuk mempercepat waktu pemampatan. Pada tanah lunak, proses pemampatan setelah adanya beban berlangsung sangat lama, dikarenakan tanah lunak akan mengalami pemampatan dengan waktu 
yang cukup lama (Indrasurya B. Muhtar 2000). Agar tidak bercampurnya tanah lunak dengan pasir, maka perlu dipasang geotekstile non-woven agar air saja yahg dapat keluar dari tanah lunak pada proses konsolidasi dan melaluai lapisan pasir sebagai saluran drainase akan mengalir melalui wadah yang telah disiapkan. Besarnya beban diatas tanah lunak diberikan dengan pelat baja dan dibiarkan bekerja pada waktu yang berbeda untuk mendapatkan besar penurunan yang berbeda, dimana akan mengalami perbedaan derajat konsolidasi sehinga besarnya penurunan akan berbeda. Penurunan pada waktu $t$ dibandingkan dengan penurunan total hasil perkiraan secara teori disebut derajat konsolidasi (U) (Das, Braja M 1988).

Besar penurunan dicatat setiap hari dengan membaca dial gauge yang terpasang, kemudian dilakukan pengambilan sampel untuk dilakukan pengujian kuat geser langsung di laboratorium, untuk mengetahui nilai parameter kuat gesernya. Maka akan didapatkan korelasi nilai parameter kuat geser tanah akibat besarnya penurunan yang terjadi dari hasil pemodelan di laboratorium. Pada penelitian ini digunakan tanah lunak Hambalang mengingat lokasi yang cukup dekat dan mudah pengambilan sampel. Juga berdasarkan hasil pengujian sampel tanah tidak terganggu (undisturbed) dari Hambalang untuk keperluan tugas akhir mahasiswa. Selain itu tanah di Hambalang dikatakan dominan lunak dan pernah mengalami permasalahan pada pelaksanaan pembangunan konstruksi, sehingga dapat mengetahui karakteristik tanah Hambalang lebih lanjut agar dapat dilakukan penanganan yang lebih teliti sebelum mendirikan suatu konstruksi di lokasi tersebut.

\section{METODE PENELITIAN}

Bak uji diisi dengan tanah berdasarkan parameter berat isi tanah asli di lapangan setinggi $50 \mathrm{~cm}$. Kemudian diberi lapisan pemisah antara tanah asli dengan lapisan pasir sebagai drainase horizontal yang menampung air hasil proses konsolidasi pada tanah akibat beban dan disalurkan pada wadah yang telah disiapkan sehingga tidak terjadi genangan air pada saat pengujian. Di atas lapisan pasir diberikan papan agar beban yang bekerja merata seluas bidang beban sehingga dapat diketahui besarnya tegangan yang terjadi dipermukaan tanah. Besarnya beban ditentukan berdasarkan kemampuan tanah lunak menerima beban maksimum sehingga tidak terjadi penurunan segera maupun kelongsoran. Waktu pembebanan diberikan bervariasi sesuai dengan perhitungan penurunan yang akan dicapai berdasarkan perkiraan teori yang dapat diketahui dari nilai parameter kuat geser tanah asli hasil pengujian di laboratorium. Setelah penurunan tercapai, maka dilakukan pengambilan sampel untuk diuji parameter.

1. Lokasi Penelitian Laboratorium Mekanika Tanah, Jurusan Teknik Sipil Politeknik Negeri Jakarta.

2. Bahan yang digunakan

a. Sampel Tanah terganggu ddari Hambalang Bogor.

b. Bahan pelengkap yang digunakan antara lain, lapisan pemisah, kertas filter, aquades, kantung plastik, tissue, paralon, paravin dan oli.

3. Peralatan yang Digunakan
a. Mesin Uji Geser Langsung
b. Saringan Tanah 1 Set
c. Hydrometer $1 \mathrm{Set}$
d. Alat Atterberg Limits 1 Set
e. Timbangan Ketelitian 0,01 gr
f. Timbangan Ketelitian 0,1 gr 
g. Oven

h. Piknometer

i. Tabung Sampel Undisturbed, dan

j. Peralatan kecil pendukung lainnya.

$\mathrm{k}$. Bak pengujian untuk mengetahui besarnya penurunan tanah akibat beban (1 set)

4. Variabel Penelitian

Variable bebas dalam penelitian ini adalah besarnya beban yang diberikan dan waktu pembebanan.

5. Teknik Pengambilan Data

Untuk mengetahui korelasi perubahan nilai kuat geser tanah lunak Hambalang berdasarkan besarnya penurunan yang terjadi,data yang diperlukan yaitu :

a. Parameter fisik tanah yang digunakan antara lain: berat volume tanah asli. kadar air, berat jenis, angka pori, koefisien penurunan, koefisien kecepatan konsolidasi, distribusi ukuran butiran sampel, nilai batas cair dan batas plastis sampel.

b. Nilai parameter kuat geser tanah asli

c. Prosedur penelitian sesuai diagram pada Gambar 1.

6. Prosedur pengujian

a. Sampel tanah terganggu hambalang dilakukan pengujian analisa ukuran butiran sampel untuk mengetahui apakah hasil uji sampel tanah tak terganggu dengan terganggu terjadi perbedaan komposisi, mengingat pengambilan sampel terganggu sedikit berbeda dengan sampel tak terganggu.

b. Sampel tanah terganggu dijemur dibawah matahari untuk mendapatkan kondisi kering udara dan memudahkan memasukkan sampel dalam bak uji.

c. Sampel dimasukkan dalam bak uji dan diberikan air setinggi sampel untuk memudahkan mendapatkan kondisi jenuh. d. Beban dibuat bervariasi pada 4 bak uji dan waktu pembebanan yang sama dimana akan menghasilkan penurunan yang berbeda.

e. Dial gauge dicatat pada ke 4 bak uji dengan waktu yang sama.

f. Setelah waktu yang ditentukan dan mendapatkan besar penurunan yang berbeda, maka sampel diambil untuk di uji geser langsung di laboratorium.

g. Sebelum di uji, masing-masing sampel ditimbang beratnya untuk mengetahui berat isi sampel yang terjadi.

h. Pengujian kadar air, dilakukan sebelum pengujian geser langsung

i. Sampel dibuat sebanyak 4 buah untuk setiap besar penurunan yang terjadi.

j. Setiap sampel diuji geser langsung dengan beban normal yang berbeda.

k. Hasil pengujian geser langsung akan mendapatkan besarnya tegangan normal dan tegangan geser, sehingga dari ke-4 sampel tersebut akan dapat diketahui berapa nilai kohesi $(\mathrm{Cu})$ dan sudut geser dalam sampel tersebut. dengan demikian setiap besar penurunan yang terjadi akan mempunyai parameter kuat geser tanah. Sehingga dapat diketahui bagaimana perubahan nilai parameter kuat geser setiap sampel.

1. Selanjutnya dibuat grafik hubungan antara besar penurunan tanah dengan kohesi, dan sudut geser dalam tanah tersebut. 


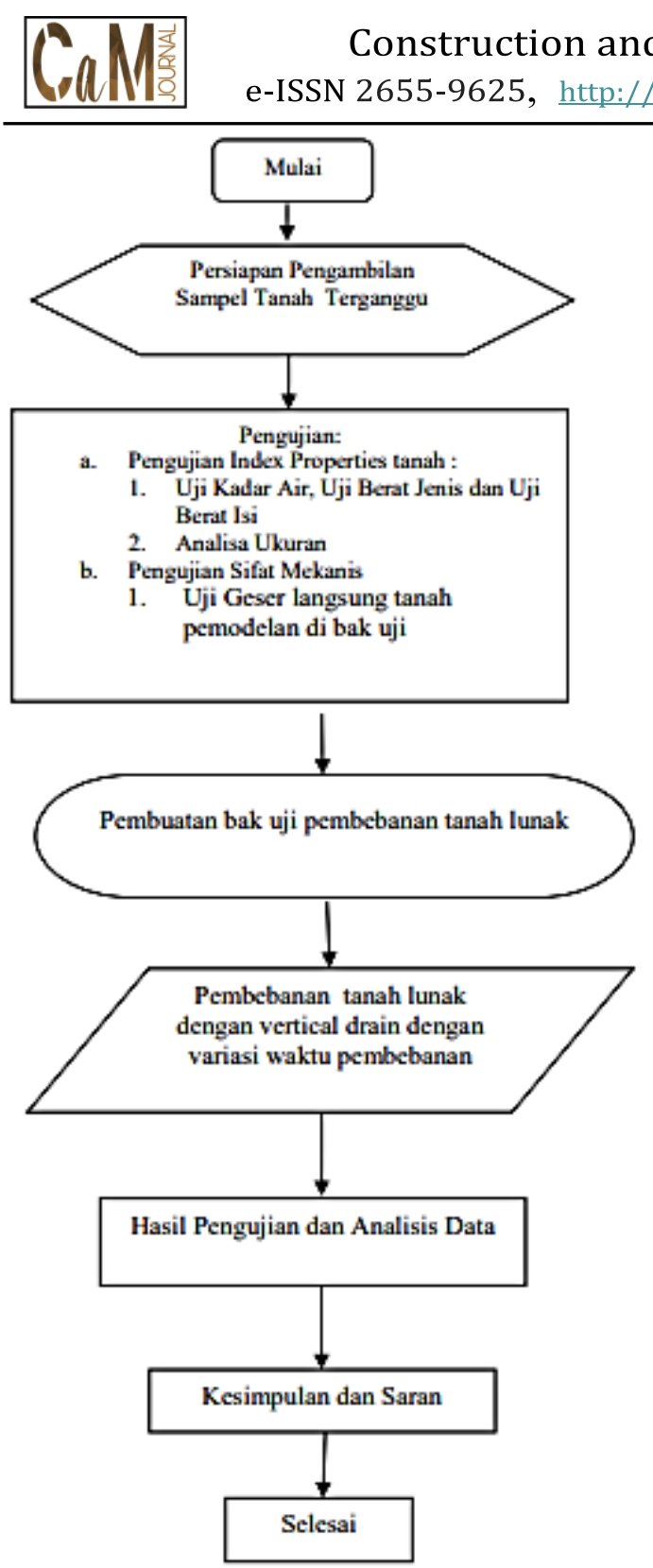

Gambar 1. Diagram alir penelitian

\section{HASIL dan PEMBAHASAN}

1. Hasil Pengujian Sifaf Fisik dan Sifat Mekanik Tanah Asli (Tanah Tak Terganggu) penelitian terdahulu sebagai berikut:
Volume 3 No. 2

Juli 2021
Tabel 1. Hasil Uji Sifat Fisik (Indeks

Properties) dan Sifat Mekanik Tanah

(Enggineering Properties) Sampel

Undisturbed

\begin{tabular}{|c|c|c|c|c|c|c|c|c|}
\hline \multicolumn{2}{|c|}{$\begin{array}{l}\text { Fropert } \\
\text { Sumpel }\end{array}$} & \multicolumn{6}{|c|}{$\begin{array}{l}\text { Pannaltian Unggulan Prodi } \\
\text { Tanan Asli (Undiasturtod } \\
\text { Sampai) }\end{array}$} & \\
\hline \multicolumn{5}{|c|}{ No.sampls } & 1 & 2 & 3 & \\
\hline \multicolumn{3}{|c|}{ Index Properties } & symbol & unit & & & & \\
\hline 1. & \multicolumn{2}{|l|}{ Densty } & $\gamma$ & $t \mathrm{~m}^{3}$ & 1.297 & 1.337 & 1.329 & \\
\hline 2 & \multicolumn{2}{|c|}{ Wotroomstent } & $\omega$ & $\%$ & 40.93 & 3358 & 2033 & \\
\hline \multirow[t]{5}{*}{3} & \multicolumn{2}{|c|}{ Bosofio of grow ty } & Gs & - & 269 & 2.67 & 268 & \\
\hline & \multicolumn{2}{|c|}{ Drydersty } & $\gamma_{s}$ & $4 / m^{3}$ & 092 & 1.00 & 1.10 & \\
\hline & \multicolumn{2}{|l|}{ Void rato } & $\mathrm{e}$ & $-\cdot$ & 192 & 1.67 & 1.42 & \\
\hline & \multicolumn{2}{|l|}{ Fonsaty } & $\mathrm{n}$ & - & 066 & 0.63 & 0.59 & \\
\hline & \multicolumn{2}{|c|}{ Degrat of a stertion } & Sr & $\%$ & 57.28 & 5377 & 3823 & \\
\hline \multirow[t]{3}{*}{4.} & \multicolumn{2}{|c|}{ Fonio Im: } & PL & $\%$ & 36.97 & 41.78 & 3079 & \\
\hline & \multicolumn{2}{|l|}{ Liquid lim : } & LL & $\%$ & 55.01 & 58.31 & 5080 & \\
\hline & \multicolumn{2}{|c|}{ Flostocty index $x$} & $\mathrm{PI}$ & $\%$ & 18.04 & 16.53 & 2001 & \\
\hline \multirow[t]{4}{*}{5.} & orins $z=$ & Grsal & G & $\%$ & 0.00 & 0.00 & 0.00 & \\
\hline & & Sand & s & $\%$ & 342 & 1.71 & 11.82 & \\
\hline & & sit & M & $\%$ & 93.49 & 95.45 & 88.18 & \\
\hline & & $\mathrm{Clay}_{\mathrm{y}}$ & c & $\%$ & 309 & 2.84 & 0.00 & \\
\hline \multicolumn{5}{|c|}{ Engineering properties } & & & & \\
\hline \multirow[t]{2}{*}{6.} & \multicolumn{2}{|c|}{ Disot Seะr Tant } & $\varphi$ & $\circ$ & - & . & 21,31 & \\
\hline & & & c & $\mathrm{kg} / \mathrm{cm}-\mathrm{s}$ & - & - & 0.088 & \\
\hline \multirow[t]{2}{*}{7.} & \multicolumn{2}{|c|}{ Consolidgtion Tant } & $\mathrm{C}_{c}$ & - & 0.720 & 0.687 & 0628 & \\
\hline & & & $\mathrm{C}_{v}$ & $\operatorname{com} 2000$ & $2775 E-02$ & $\begin{array}{l}4.600 E- \\
02-\end{array}$ & $\begin{array}{l}4.442 E- \\
02-\end{array}$ & \\
\hline
\end{tabular}

Tabel 2. Konsistensi Tanah (untuk tanah dominan lanau dan lempung)

\begin{tabular}{|c|c|c|c|c|c|}
\hline \multirow[t]{2}{*}{$\begin{array}{l}\text { Konsisten } \\
\text { si }\end{array}$} & \multicolumn{2}{|c|}{$\begin{array}{l}\text { Taksiran harga } \\
\text { kekuatan geser } \\
\text { undrained, } \mathrm{Cu}\end{array}$} & \multirow{2}{*}{$\begin{array}{c}\text { Taksiran } \\
\text { harga } \\
\text { SPT, } \\
\text { harga N }\end{array}$} & \multicolumn{2}{|c|}{$\begin{array}{l}\text { Taksiran harga tahanan } \\
\text { conus, qc (dari Sondir) }\end{array}$} \\
\hline & $\mathrm{kPa}$ & ton/ $\mathrm{m} 2$ & & $\mathrm{~kg} / \mathrm{cm} 2$ & $\mathrm{kPa}$ \\
\hline $\begin{array}{l}\text { Sangat } \\
\text { Lunak } \\
\text { (very } \\
\text { soft) }\end{array}$ & $0-12.5$ & $0-1.25$ & $0-2.5$ & $0-10$ & $\begin{array}{c}0- \\
1000\end{array}$ \\
\hline $\begin{array}{l}\text { Lunak } \\
\text { (soft) }\end{array}$ & $\begin{array}{c}12.5- \\
25\end{array}$ & $\begin{array}{r}1.25- \\
2.5\end{array}$ & $2.5-5$ & 10. -20 & $\begin{array}{c}1000- \\
2000\end{array}$ \\
\hline $\begin{array}{l}\text { Menenga } \\
\mathrm{h} \\
\text { (medium }\end{array}$ & $25-50$ & $2.5-5$ & $\begin{array}{c}5.0- \\
10\end{array}$ & $20-40$ & $\begin{array}{c}2000- \\
4000\end{array}$ \\
\hline $\begin{array}{l}\text { Kaku } \\
\text { (stiff) }\end{array}$ & $\begin{array}{l}50- \\
100\end{array}$ & $5-10$ & $10-20$ & $40-75$ & $\begin{array}{c}4000- \\
7500\end{array}$ \\
\hline $\begin{array}{l}\text { Sangat } \\
\text { kaku } \\
\text { (very } \\
\text { stiff) }\end{array}$ & $\begin{array}{l}100- \\
200\end{array}$ & $10-20$ & $20-40$ & $75-150$ & $\begin{array}{l}7500- \\
15000\end{array}$ \\
\hline $\begin{array}{l}\text { Keras } \\
\text { (hard) }\end{array}$ & $>200$ & $>20$ & $>40$ & $>150$ & $>15000$ \\
\hline
\end{tabular}

(Sumber: Mochtar, 2006; revised, 2012)

Dari hasil uji tanah Hambalang yang tak terganggu dapat diketahui memiliki berat volume yang kecil sesuai dengan kriteria tanah lunak. Kemudian berdasarkan tabel 2 nilai dari cohesi tanah Hambalang $0,8 \mathrm{~kg} / \mathrm{cm}^{2}$, maka termasuk tanah sangat lunak. 
Gradasi butiran tanah dominan halus karena lolos saringan No 200, rata-rata diatas $90 \%$, dan berdasarkan plasticity chart termasuk MH.

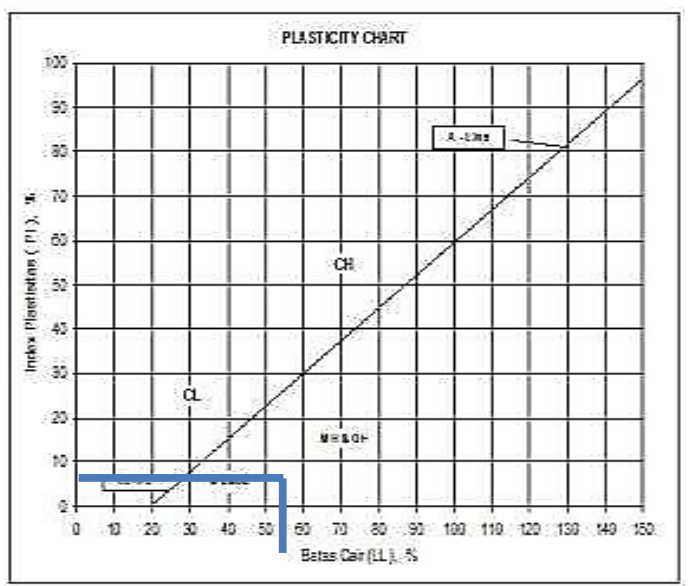

Gambar 1. Grafik Plasticity Chart (sumber Das, Braja M)

2. Hasil Pengujian Gradasi sampel tanah terganggu (Disturbed)

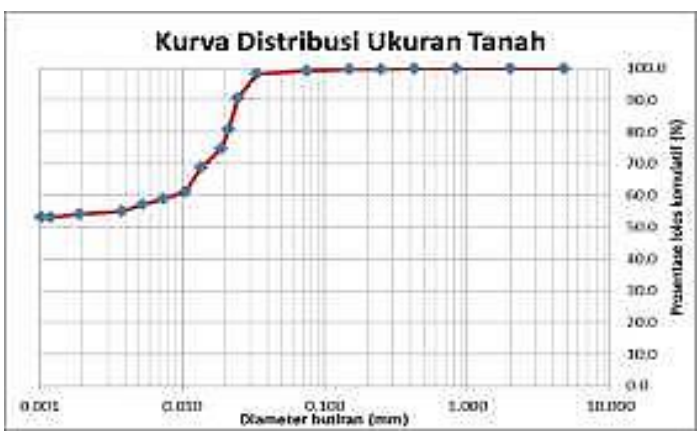

Gambar 2. Gradasi Ukuran Butiran Sampel 1

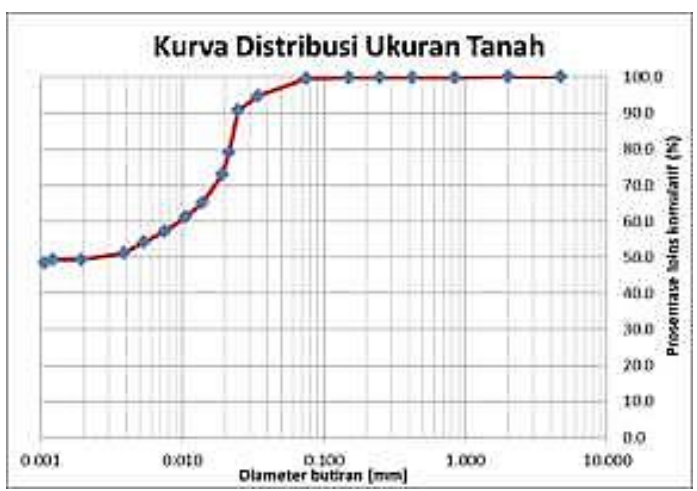

Gambar 3. Gradasi Ukuran Butiran

Sampel 2

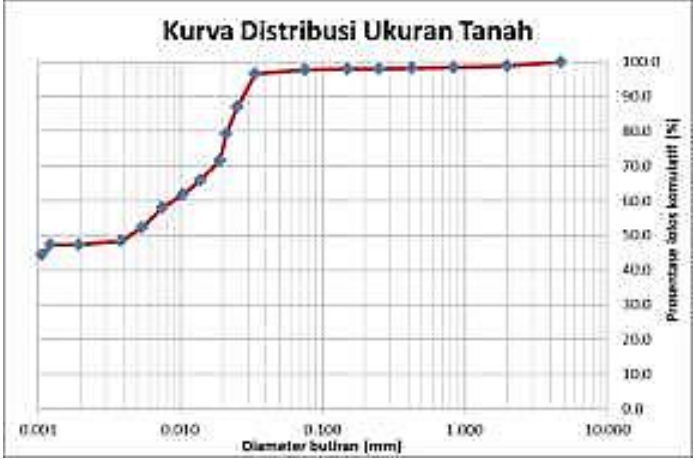

Gambar 4. Gradasi Ukuran Butiran Sampel 3

Untuk mengetahui lebih tepatnya tanah yang digunakan maka dilakukan analisa ukuran butiran yaitu uji ayakan dan hydrometer, dilakukan pada 3 sampel. Dari hasil yang didapat terlihat pada Gambar 2, 3 dan 4, ternyata tanah terganggu Hambalang yang digunakan pada penelitian ini mengandung lempung dengan kadarnya rata-rata $50 \%$.

3. Hasil Uji Geser Langsung tanah berdasarkan besar penurunan tanah.

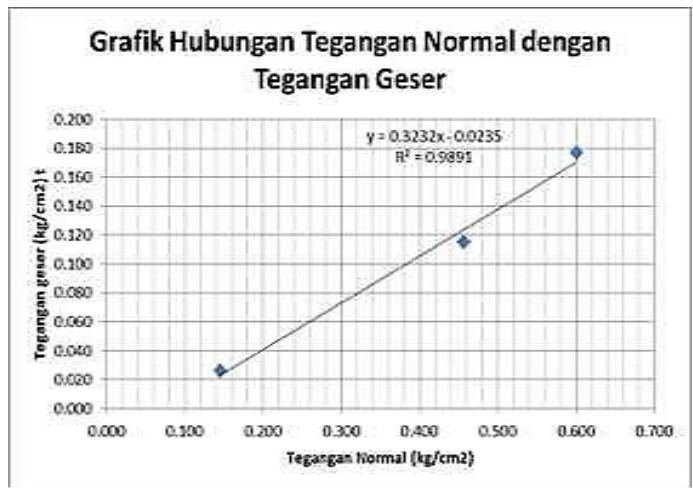

Gambar 5. Grafik Hubungan Tegangan Normal dan Tegangan Geser pada Penurunan Tanah 4,24 mm 


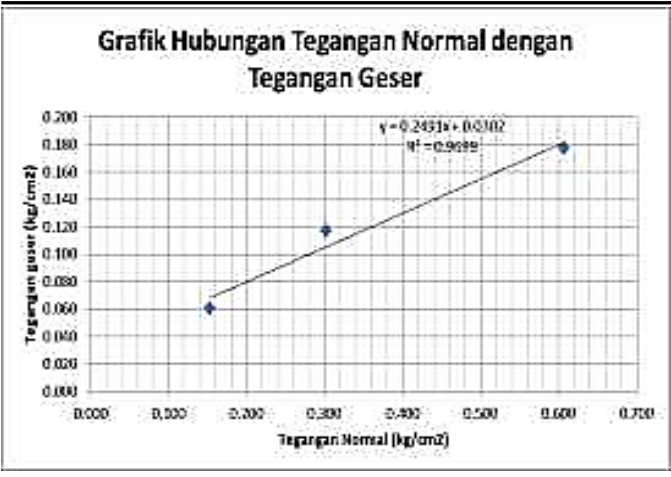

Gambar 6. Grafik Hubungan

Tegangan Normal dan Tegangan Geser pada Penurunan Tanah 6,57 mm

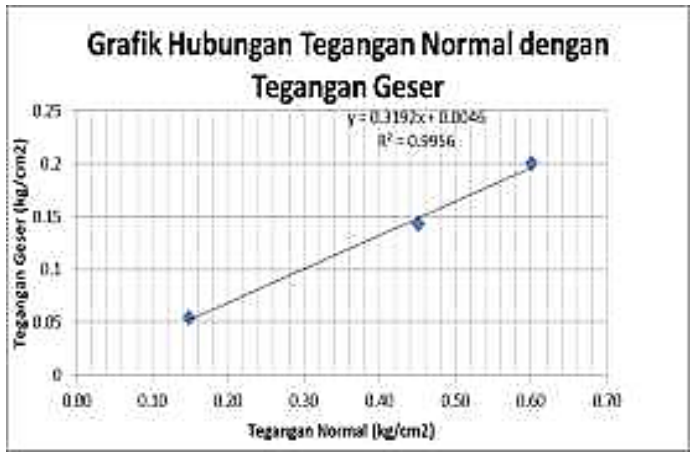

Gambar 7. Grafik Hubungan

Tegangan Normal dan Tegangan Geser pada Penurunan Tanah 7,30 mm

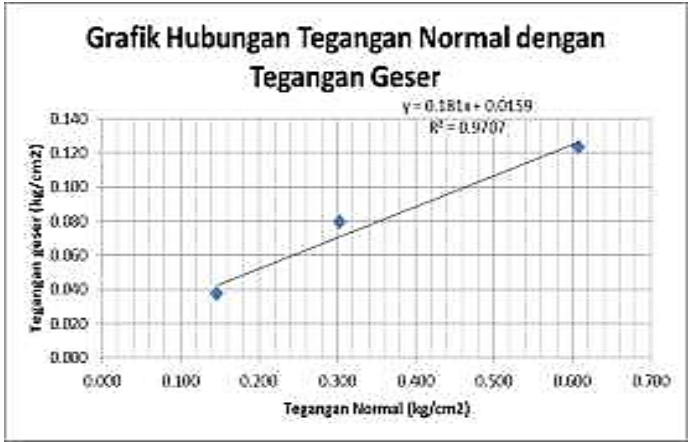

Gambar 8. Grafik Hubungan

Tegangan Normal dan Tegangan Geser pada Penurunan Tanah 9,53 mm

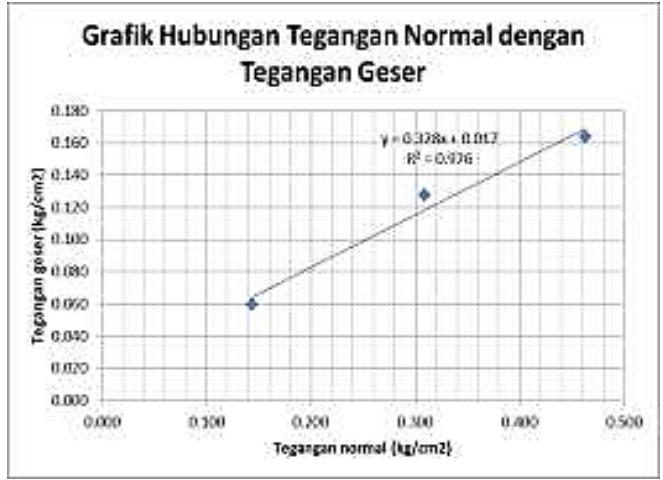

Gambar 9. Grafik Hubungan Tegangan Normal dan Tegangan Geser pada Penurunan Tanah $10 \mathrm{~mm}$

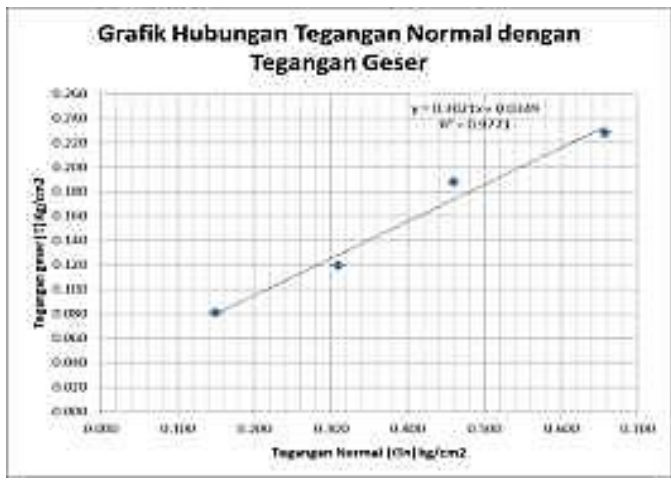

Gambar 10. Grafik Hubungan Tegangan Normal dan Tegangan Geser pada Penurunan Tanah 16,8mm

4. Hubungan nilai Kohesi (C) dengan penurunan tanah, pada gambar dibawah ini.

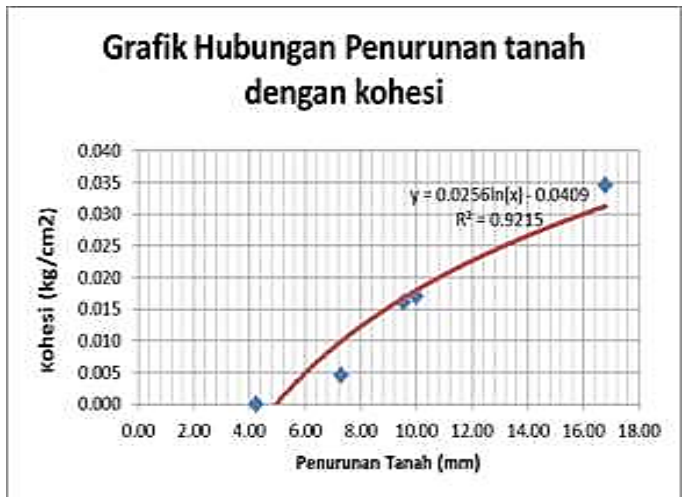

Gambar 11. Grafik Hubungan Besar penurunan tanah dan Kohesi Tanah (C)

Hasil yang didapatkan seperti terlihat pada Gambar 11, bahwa penrunan tanah mempengaruhi perubahan nilai kohesi tanah, dimana semakin besar 
penurunan tanah yang terjadi, maka nilai kohesi akan bertambah, tetapi ada kecenderungan mengalami puncak, kemungkinan ada pada kondisi tetap jika penurunan bertambah. Bisa saja hal ini terjadi karena tanah sudah mengalami kepadatan yang maksimum sehingga nilai kohesi tidak mengalami perubahan, artinya tanah sudah mengalami pemampatan primer tidak terjadi lagi, atau mencapai derajat konsolidasi $100 \%$.

5. Hubungan nilai sudut geser dalam $(\phi)$ dengan penurunan tanah, ditunjukkan pada Gambar 12.

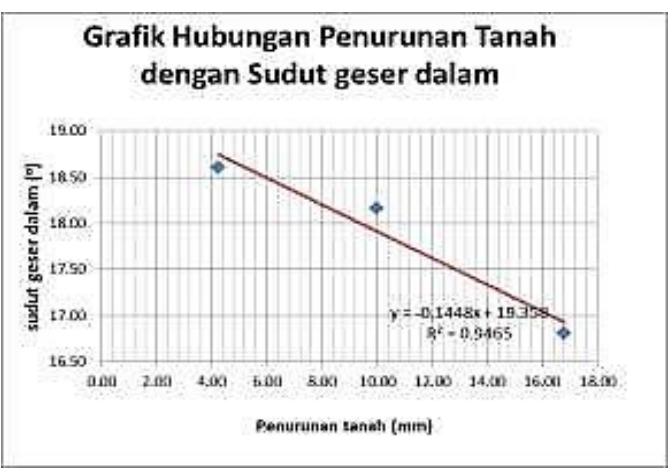

Gambar 12. Grafik Hubungan Besar penurunan tanah dan Sudut geser dalam

$(\phi)$

Berdasarkan Gambar 12, menunjukkan bahwa hubungan nilai sudut geser dalam $(\phi)$ berbanding terbalik dengan penurunan yang terjadi. Semakin besar penurunan yang terjadi semakin kecil sudut geser dalam $(\phi)$ tanah tersebut.

6. Nilai kepadatan tanah akibat besar penurunan tanah.

Hubungan nilai kepadatan tanah akibat besarnya penurunan tanah yang terjadi ditunjukkan pada Gambar 13.

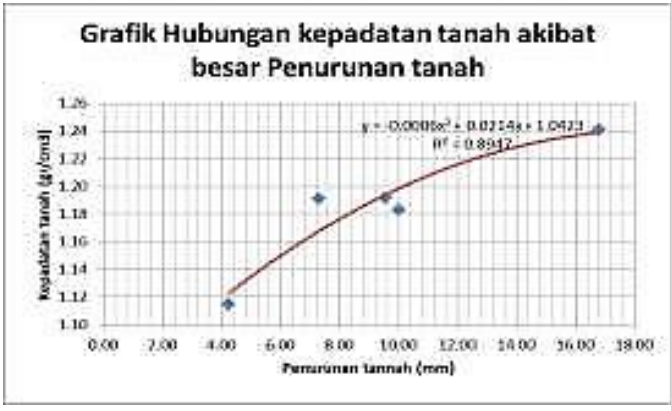

Gambar 13. Grafik Hubungan Besar

Penurunan Tanah dan Kepadatan Tanah

Akibat pemampatan tanah, maka kepadatan tanah mengalami perubahan. Hasil yang didapat seperti pada Gambar 13. Kepadatan tanah berbading lurus terhadap besar penurunan tanah yang terjadi tetapi tidak linier secara signifikan, karena kepadatan tanah akan mengalami pada puncaknya, maka kemungkinan kepadat tanah akan tetap karena pemampatan yang sudah selesai maka kepadatan tanahpun tidak akan bertambah.peningkatan akibat besar penurunan yang terjadi.

7. Nilai kadar air akibat besar penurunan tanah

Kadar air sangat memegang peranan penting pada tanah berbutir halus terhadap kekuatan tanahnya, sehingga kadar air harus diperhatikan. Hasil pemodelan menunjukkan bahwa nilai kadar air mengalami perubahan akibat penurunan yang terjadi, seperti gambar dibawah ini.

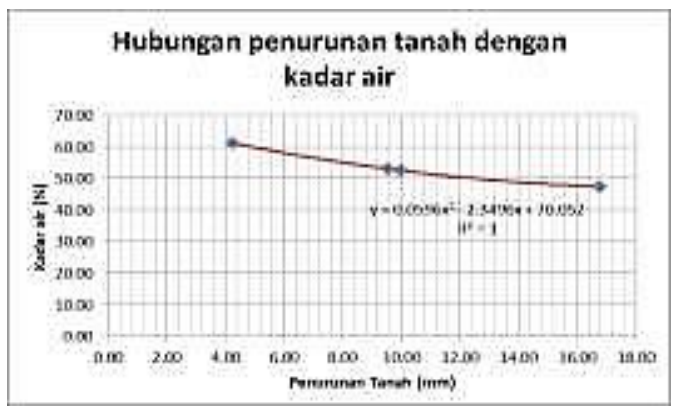

Gambar 14. Grafik Hubungan Besar Penurunan Tanah dan Kepadatan Tanah 


\section{KESIMPULAN}

Berdasarkan penelitian yang telah dilakukan, dapat disimpulkan sebagai berikut:

1. Hasil pengujian undisturbed sampel tanah Hambalang menunjukkan tanah sangat lunak dengan High plasticity dan berjenis Lanau $(\mathrm{MH})$ dan menurut uji geser langsung nilai $\mathrm{C}=$ $0,088 \mathrm{~kg} / \mathrm{cm}^{2}$ dan nilai sudut geser dalamnya $(\theta)$ sebesar $21,31^{\circ}$.

2. Hasil pengujian disturbed sampel tanah hambalang yang ditingkatkan kadar airnya pada pengujian, menunjukkan terjadi penuruan parameter kuat gesernya. Nilai kohesi berbanding lurus dengan besar penurunan, nilai sudut geser dala berbading terbalik, kepadatan berbading lurus dan kadar air berbanding terbalik

3. Hasil pengujian analisa diameter butiran tanah Hambalang disturbed memiliki komposisi yang berbeda. Pada sampel disturbed memiliki kandungan lempung sehingga tanahnya termasuk lempung.

\section{UCAPAN TERIMAKASIH}

Ucapan terima kasih disampaikan kepada UP2M Politeknik Negeri Jakarta yang telah mendanai penelitian ini dan pihak yang telah membantu dalam melakukan penelitian dilaboratorium Mekanika Tanah Jurusan Teknik Sipil Politeknik Negeri Jakarta.

\section{DAFTAR PUSTAKA}

[1] Wibawa Arif, Endang Setyawati Hisyam. 2015. Pengaruh Penambahan Limbah Gypsum Terhadap Nilai Kuat Geser Tanah Lempung. Jurnal Fropil Vol 3 Nomor 2 Juli-Desember 2015. http://www.journal.ubb.ac.id/inde x.php/ fropil/article/view/1214
DOI:

https://doi.org/10.33019/fropil.v3 i2.1214

[2] Arinda Rahma, Arinda dkk. 2018. Pengaruh Kadar Air Terhadap Daya Dukung Pada Tanah Lunak Di Jalan Tol Gempol - Pasuruan (The Influence Of Water Content To Bearing Capacity Of Soft Soil As Subgrade of Pavement In Gempol - Pasuruan). Jurnal Mahasiswa Jurusan Teknik Sipil Universitas Brawijaya

[3] Widio Ario Laras dkk. 2017. Pengaruh Penambahan Kapur Dengan Lamanya Waktu Perawatan (Curing) Terhadap Kekuatan Dan Pengembangan (Swelling) Tanah Lempung Ekspansif, Jurnal Mahasiswa Jurusan Teknik Sipil Universitas Brawijaya.

[4] Das, Braja M. 1985. Mekanika Tanah (Prinsip-prinsip Rekayasa Geoteknis) Jilid 1\&2. Terjemahan oleh Noor Endah dan Indrasurya B. Mochtar. Jakarta: Erlangga

[5] Indrasurya B. Mochtar 2000, Teknologi Perbaikan tanah dan Alternatif perencanaan pada tanah bermasalah. Buku ajar Teknik Sipil ITS,2000

[6] Indrasurya B. Mochtar. 2012, Kenyataan Lapangan sebagai dasar untuk usulan konsep baru tentang analisa kuat geser tanah dan kestabilan lereng, 16th Annual Scientific Meeting 2012

[7] Mersi Yermia Hontong dkk.2019; Perubahan Nilai Parameter Kuat Geser Tanah Akibat Siklus Pembasahan Dan Pengeringan, Prosiding Seminar Nasional Teknik Sipil Politeknik Negeri Jakarta 2019.

[8] Wahyu Wijaya. Istiatun,2017 :Studi Nilai Parameter Geser Tanah Berdasarkan Penurunan Akibat Beban Dan Waktu Pembebanan, Skripsi Program 
Studi Sarjana Terapan pada Jurusan Teknik Sipil Politeknik Negeri Jakarta.

[9] Wahyu P. Kuswanda. 2015, Perbaikan Tanah Lempung Lunak Metoda Preloading pada Pembangunan Infrastruktur Transportasi Di Pulau Kalimantan.Prosiding Seminar
Politeknik Negeri Banjarmasin.

[10] Zahrotus Saadah, 2020, Sudi Konstruksi Timbunan pada Oprit Fly Over Jalan Arteri Raya Siring Porong Sidoarjo, Skripsi Program Studi Sarjana Terapan pada Jurusan Teknik Sipil ITS, Surabaya. 